\title{
土地費用の上昇に伴う地域施設複合化のモデル分析 MODELING EMERGENCE OF MULTIPLE SERVICE FACILITIES ACCORDING TO INCREASE IN LAND COST
}

\author{
鈴木 勉* \\ Tsutomu SUZUKI
}

\begin{abstract}
Multiple service facilities can often save total cost for provision of service because of the economies of scale associated with facility size and the ability to share resources including land. In this paper, two multiple service facility location problems are formulated as minimization problems of the sum of travel cost and building cost of facilities. One assumes that the total number of facilities is given exogenously, and the other assumes that the total number of facilities is determined endogenously. Some numerical examples show that co-location of different type of facilities increases as land cost increases for the exogenous case. Similarly, co-location of facilities increases as land cost increases for the endogenous case while keeping the number of facilities large.
\end{abstract}

Keywords: multiple service facilities, facility location, p-median problem, travel distance, land cost 複合施設, 施設配置, $p$-メディアン問題, 移動距離, 土地費用

1.はじめに

複数種の施設が同一敷地に立地する形式の複合施設（以下，空間 複合型施設と呼ぶ）を設置する理由は，地方部では主に自治体の財 政力不足に起因する管理運営の合理化にあることが多いが，大都市 中心部では多くの場合，高地価による公共用地難を背景とする土 地・空間の高度利用にある．現に東京都区部では，少ない公共用地 の有効利用の一方策として，小学校の全面的な改築や新設の際に, 幼稚園や児童館, 保育所, デイサービスセンター，特別養護老人ホ 一ム，公民館，図書館等との本格的な複合施設を建設するといった 事例が多く見られるようになってきている。 ${ }^{518) 91101 ~}$

このような複数種の機能を併せ持つ施設を設置する場合，それぞ れの機能について施設が適正に配置されているかに注意が払われな ければならない。このような観点から，岸本 $\left.(2000)^{2}\right)$ は多層的な構造 を持った施設群の最適配置を求める手法を開発し、これを複合施設 の最適配置に適用している，また，鈴木 $(2001)^{7}$ は，有限領域内での 空間複合型施設の最適配置が均等配置とならないことを明らかにし ている.

しかしこれらの研究では, 施設の複合化がまずありきとしており， 複合化形成の仕組みは論じられていない。土地代の高い大都市中心 部における空間高度利用を想定するならば，図1に示すように，土
地代が安い場合は，いくつかの種類の施設をそれぞれ個別に適正に 配置した方が施設までの距離は短くなり，利用者の利便は高まる. しかし，土地代が高くなるにつれて，施設を複合化することによっ て施設までの距離を多少犠牲にしてでも設置場所数を減らし，施設 設置のための土地費用の増大を抑えようとするであろう．大都市部 での施設複合化の是非を議論するためには，このような複合化によ り土地費用が節約できるような構造を定量的に議論する必要がある. そこで本稿では，上述のような空間複合型施設の配置決定を複数 種類の施設の離散立地モデルとして定式化し，土地代の上昇に伴っ て空間複合型施設が出現する仕組みを最適配置モデルに基づき導出 し，その解の性質を明らかにすることを目的とする. 実際の地域施 設の配置は, ニュータウン開発における地域施設配置等でない限り， 自治体所有地等を候補地点として有効に活用する場合が多いが, 本 論文では複合施設の配置過程を再現する規範的モデルを構築するこ とに主眼を置き，立地可能場所に関して制約はないものと考える.

2 章では, 離散型配置問題である $p$-メディアン問題をベースに, 施設数を所与とした複数種の施設に対して，複合化により土地費用 が節約できるような構造を持った空間複合型施設の最適配置問題を 定式化する．３章では，さらに施設数を内生化した空間複合型施設 配置問題を定式化する. 4 章では, これらの問題の求解例を示し,
筑波大学社会工学系 講師・博士 (工学)

アルバー夕大学理学部地球大気科学科 客員研究貝
Assistant Prof., Institute of Policy and Planning Sciences, University of Tsukuba, Dr. Eng.

Visiting Scientist, Dept. of Earth and Atmospheric Sciences, University of Alberta 


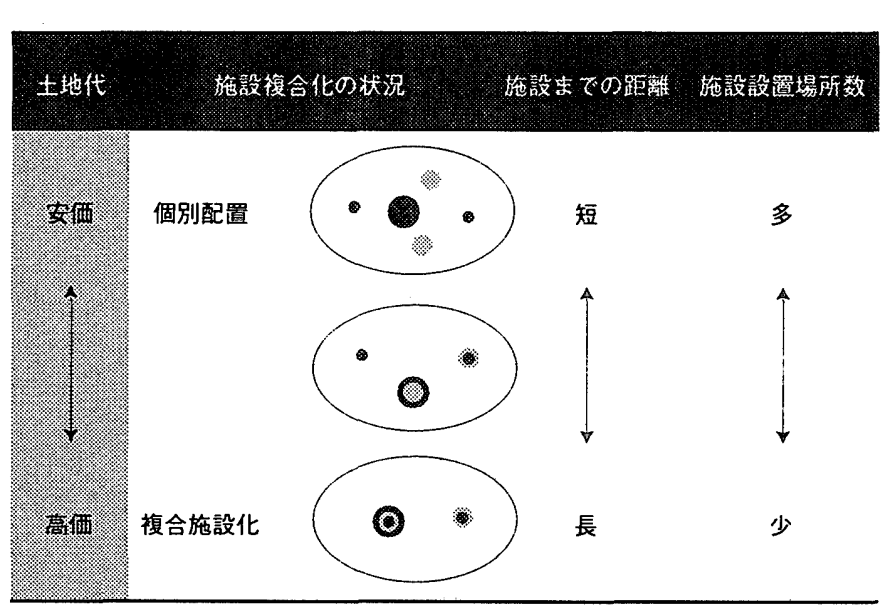

図 1 土地代と施設配置パターンの対応関係.

土地代の上昇と複合化の進行の関係を分析する。 そして 5 章で，本 論文の結論と課題をまとめる。

\section{2. 施設数を所与とする空間複合型施設配置モデル}

本章ではまず，複数種の施設に対してそれぞれの種類の施設数が あらかじめ決まっている場合について, 空間複合型施設の最適配置 問題を，p-メディアン問題 13をべースに定式化する。

いま, 施設の種類は $k$ 種類あるとし, それぞれの種類の施設の配 置は, p-メディアン問題で目的関数となる利用者の総移動費用（移 動距離に比例すると仮定）に加えて，土地費用との総和が最小にな るように決定されるものとする．このときまず，2 種類以上の施設 が同じ場所に立地する場合, 複合施設となることで土地費用が 1 施 設分で済む場合（これを土地統合可能な場合と呼ぶ）を考えよう。 但し，モデルを簡単にするため，どの種類の施設も同一の土地面積 を必要とする,すなわち, 何らかの施設が立地すれば一定の土地費 用が必要となるものと仮定する。このとき，上記の問題は以下のよ うに定式化できる。

$$
\begin{array}{cl}
\min _{\left\{X_{i j k}\right\},\left\{Z_{j}\right\}} & T=\sum_{j} p_{j} Z_{j}+\sum_{i, j, k} \alpha_{k} h_{i k} d_{i j} X_{i j k}, \\
\text { subject to } & \sum_{j} X_{i j k}=1, \quad \forall i, k, \\
& X_{i j k} \leq X_{i j k}, \quad \forall i, j, k, \\
& \sum_{j} X_{i j k}=m_{k}, \quad \forall k, \\
& Z_{j}=\max _{k}\left(X_{i j k}\right), \quad \forall j
\end{array}
$$

但し,

$X_{i j k} \in\{0,1\}$ : 候補地 $j$ の種類 $k$ の施設への地点 $i$ の需要の配分

$Z_{j} \in\{0,1\}$ : 候補地 $j$ の施設立地

$h_{i k}:$ 地点 $i$ の種類 $k$ の需要

$p_{j}:$ 侯補地 $j$ の土地代 (円)

$d_{i j}:$ 地点 $i$ から候補地 $j$ までの距離

$m_{k}:$ 種類 $k$ の施設数 (所与)

$\alpha_{k}:$ 種類 $k$ の移動費用換算係数 (円 $/ \mathrm{m}$ 人)

$T$ : 総費用

である.(1)式は目的関数であり，第一項は土地費用を，第二項は移 動費用を表す（2)式は需要のいずれかの施設への割当を保証するも のであり，(3)式はそれが $j$ に施設が立地した場合のみであることを
規定している． $X_{j j k}=1$ ならば候補地 $j$ に種類 $k$ の施設が立地するこ とを意味する. (4)式は各種類の施設数であり，(5)式は $Z_{j}$ の定義を示 す. (5)は線形制約式

$$
Z_{j} \leq \sum_{k} X_{j j k} \leq K Z_{j}, \quad \forall j
$$

で代用することができる（但し $K$ は種類数を表す）。これにより， 上記の問題は線形 0-1 計画問題として解くことができる.

土地代が 0 の場合 $\left(p_{j}=0, \forall j\right)$ は(1)式の目的関数が $k$ について分離で きるので, 各種類の施設の $p$-メディアンの重ね合わせが解となる. また，比較のために 2 種類以上の施設が同じ場所に立地しても別々 の土地が必要な場合（これを土地統合不可能な場合と呼ぶ）を考え ると、総施設数が決まっているので, 最適配置は明らかに土地代が 0.の場合の解と同一になる.

\section{3. 施設数を内生化した空間複合型施設配置モデル}

2 章では種類別の施設数が予め与えられていた場合を考えたが， 移動費用と施設設置費用のバランスを勘案しながらそれぞれの施設 を何ヶ所設置するかを決定することも多い。そこで本章では，もう 一つのモデルとして, 各施設数を内生的に決定する空間複合型施設 の最適配置問題を定式化する。

前提は 2 章と全く同じであるが，施設数が可変なため，新たに施 設の建設費を考慮する．土地統合可能な場合，総費用，すなわち， 土地費用，建設費用および移動費用の総和を最小化する問題は，以 下のように定式化できる.

$$
\begin{array}{cl}
\min _{\left\{X_{i j k}\right\},\left\{Z_{j}\right\}} & T=\sum_{j}\left(p_{j} Z_{j}+\sum_{k} q_{j k} X_{j j k}\right)+\sum_{i, j, k} \alpha_{k} h_{i k} d_{i j} X_{i j k},(6) \\
\text { subject to } & \sum_{j} X_{i j k}=1, \quad \forall i, k, \\
& X_{i j k} \leq X_{j j k}, \quad \forall i, j, k, \\
& Z_{j}=\max _{k}\left(X_{j j k}\right), \quad \forall j
\end{array}
$$

但し,

$$
q_{j k}: \text { 候補地 } j \text { の種類 } k \text { の施設の建設費 (円) }
$$

である. (6)式の第一項は土地費用と建設費用を表す．施設数制約を 表す(4)式は省かれているが，この問題で決定される施設数は(4)式を 用いて求まる。 また，(5)式は 2 章同様 $\left(5^{\prime}\right)$ 式で代替できるので，これ も線形 0-1 計画問題として解くことができる.

土地統合不可能な場合については, 目的関数を

$$
\min _{\left\{X_{j j k}\right\},\left\{Z_{j}\right\}} \quad T=\sum_{j} \sum_{k}\left(\left(p_{j}+q_{j k}\right) X_{j i k}\right)+\sum_{i, j, k} \alpha_{k} h_{i k} d_{i j} X_{i j k} \text {, (7) }
$$

で置き換えることにより求められる。但し，制約式(5)は不要となる，

\section{4. 土地代の上昇と施設複合化の関係の分析}

以上のモデルを基に，土地代の上昇につれて各種施設の最適配置 がどのように変化していくかを見てみよう。

(1) 対象の設定

東京都心区から抽出したネットワーク（町丁目代表点分布から

表 1 施設種類別パラメー夕設定 

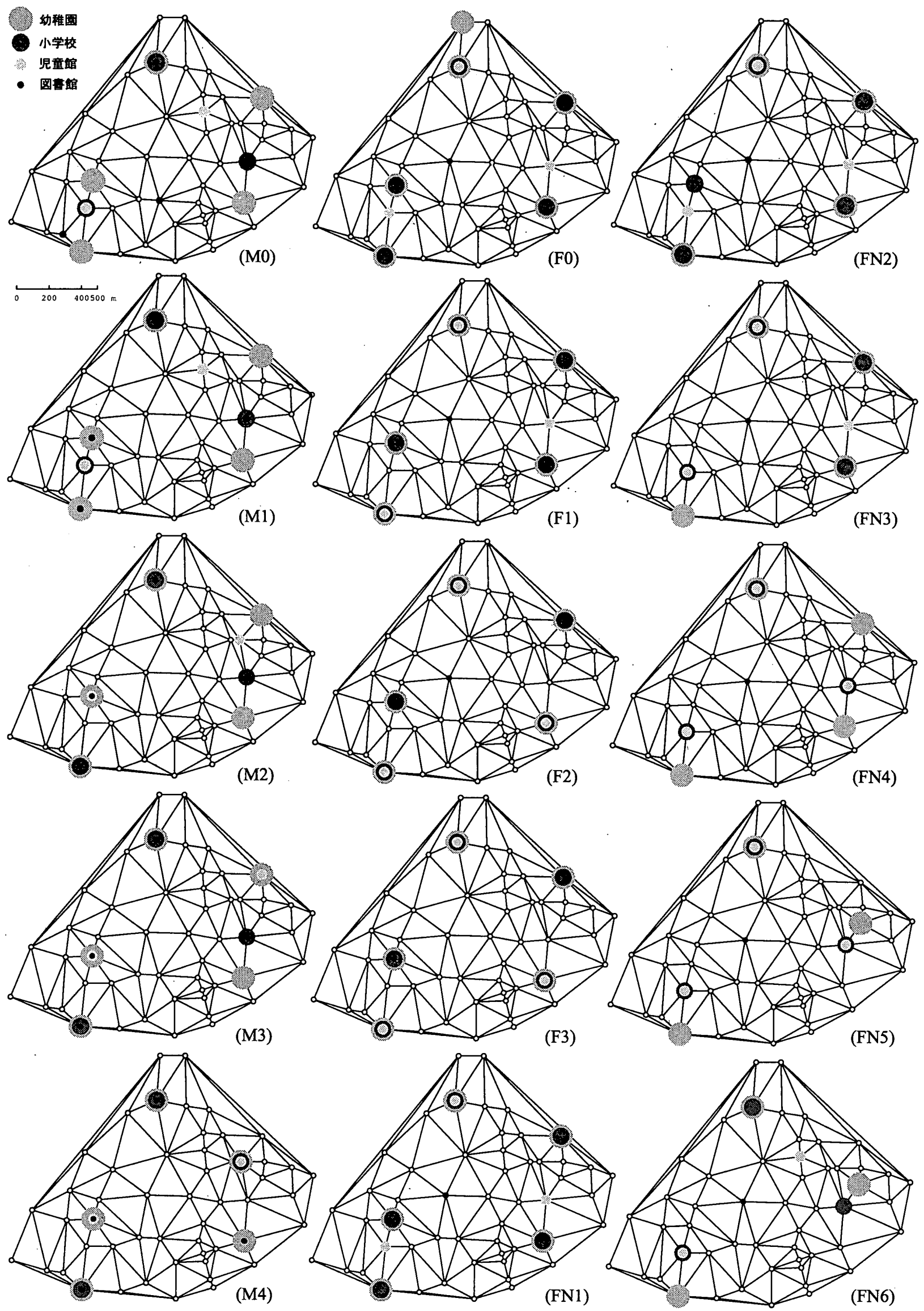

図 2 ケース別の各種施設の最適配置.

(施設数所与 $=\mathrm{M}$ ，施設数内生 -土地統合可能 $=\mathrm{F}$ ，施設数内生 -土地統合不可能=FN) 
表 2 空間複合型施設配置モデルによる計算結果

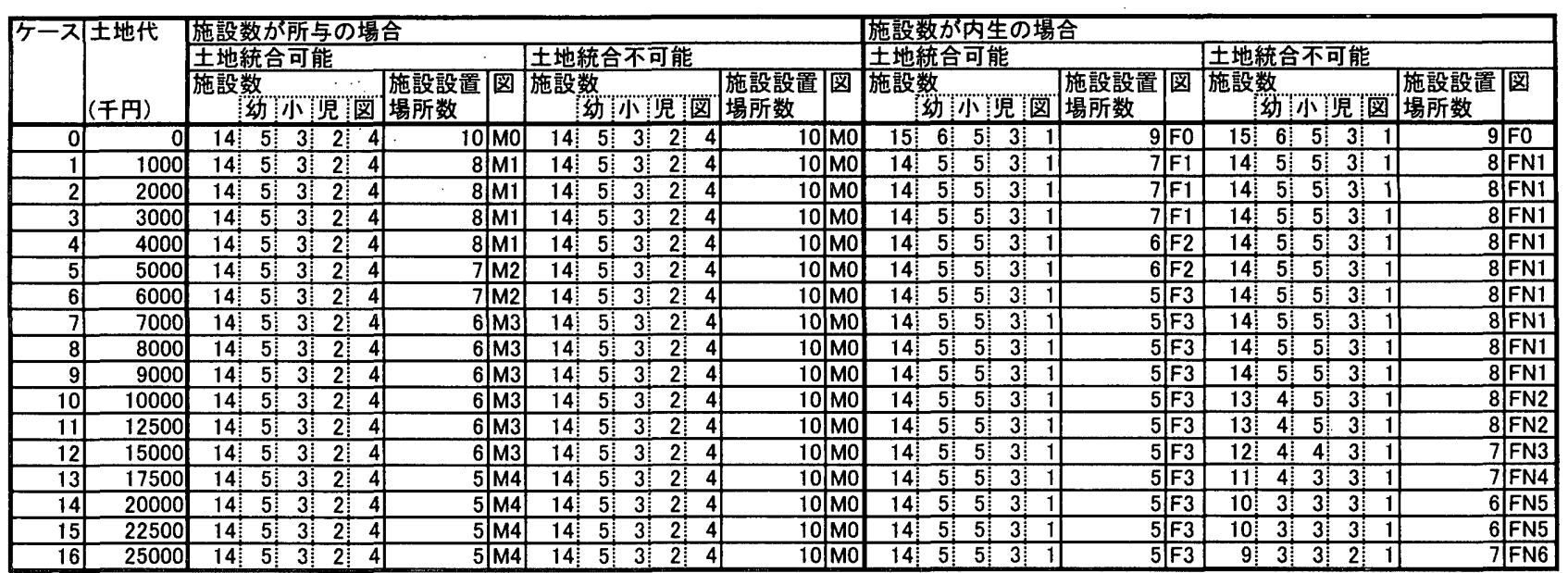
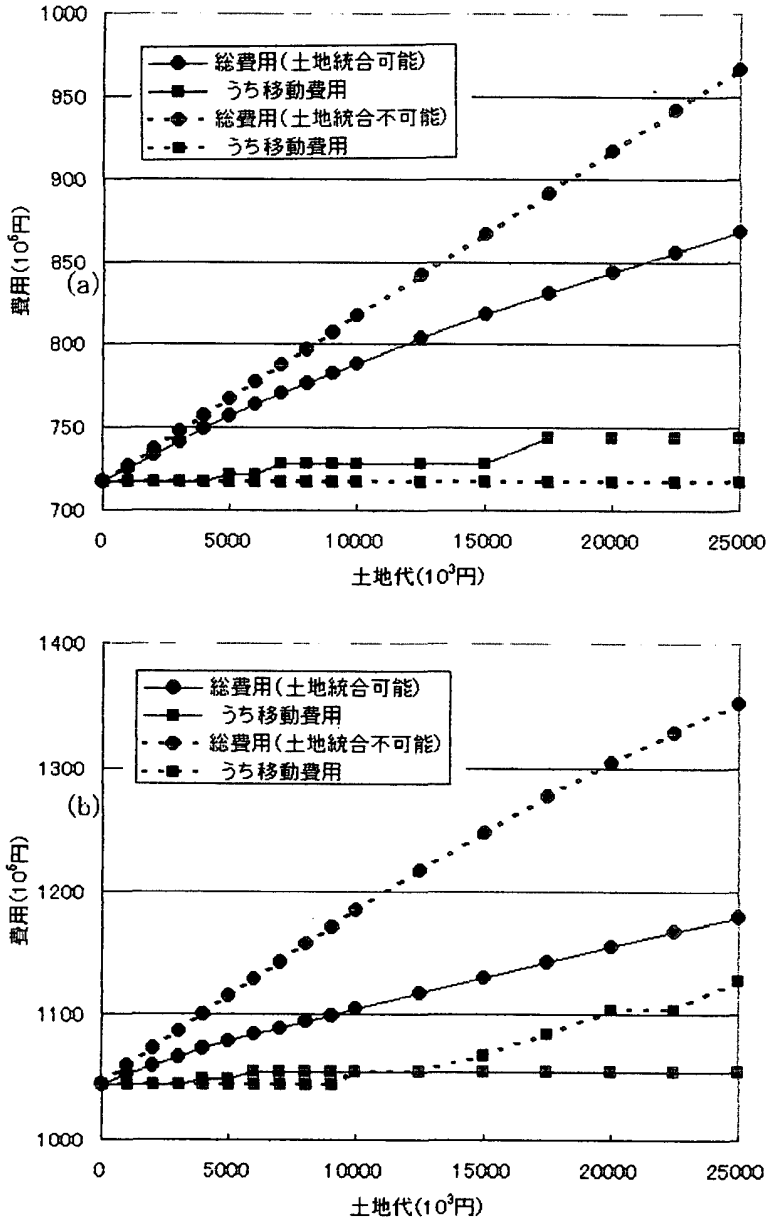

图 3 土地代と総費用の関倸 : (a)施設数所与, (b) 施設数内生

Delaunay 三角形網を作成 ; ノード数 52, リンク数 143) 上に, 幼稚 園・小学校・坚童館・図書館を設置するという問題 $(K=4)$ を，そ れぞれの需要には対応年齢人口として想定した值を与えた上で考え る. 施設種類毎のパラメータの值は表 1 に示すとおりとし, 1 施設 当たりの土地代は, 表 2 の計 17 ケースを考えることにする. 建設費 としては, 施設寿命を 50 年と設定して, 各施設の標準床面積に比例
した建設費用を寿命で除した值を与えており，移動費用換算係数と しては，東京特別区における施設密度を基準に平均距離に対する限 界建設費を与えている。ここでは，どの地点に立地しても土地代や 建設費は同じものとする．また，距離はネットワーク上の最短距離 を用いる. 求解には数理システム社の NUOPT 3.1 を用いる.

（2）施設数所与の場合の複合化

各ケースの最適配置は表 2 および図 2 に示されている. 表 2 には, 各種類の施設数と延べ施設設置場所数，そして図 2 の最適配置との 対応コード（施設数所与 $=\mathrm{M}$ ，施設数内生・土地統合可能 $=\mathrm{F}$ ，施設数 内生・土地統合不可能=FN）が示されている.

まず，施設数が所与の場合の最適配置を考える. 幼稚園・小学校・ 児童館・図書館の設置施設数がそれぞれ 5, 3,2,4 ケ所と与えられて いるとき, 土地統合可能な場合の最適配置は, 図 2 の(M0) (M4)の ようになる.土地代が全くかからない(M0)の最適配置は，各種類の 施設の $p$-メディアン問題の解の重ね合わせとなる。この場合、たま たま複合化した施設の組も見られるが，一般には施設の種類毎に需 要の空間的分布や設置施設数に差があるため, 計 14 個の施設の最適 配置はそれぞれ異なり，計 10 ケ所に施設が設置される. 土地代が上 昇するのに伴い, 最適配置は(M1) (M2) (M3) (M4) と変化していく. まず(M1)では利用人口は多いが, 移動費用換算係数の最も小さい図 書館が幼稚園の位置に統合，(M2)では続く児童館や小学校も同様に 統合され，(M3) (M4)ではさらに，同種の施設は一定の間隔を保つよ うに調整されながら施設の統合が進行している。この過程で, 移動 費用よりも複合施設による土地費用の節約が優先され，施設配置を p-メディアンからずらすことによって施設同士を空間的に複合化し， 施設設置場所数をそれぞれ 8,7,6,5 ケ所と堿少させていることが読 み取れる．施設数の中で最大のものは幼稚園の 5 であるので，(M4) 以上の複合化は起こらない.

このように，土地代が高くなると複合化が有利になり，同じ場所 に複数の施設が立地するパターンが最良になることがわかる。この とき，土地代の変化によって総費用およびそのうちの移動費用分が どのように変化するかは図 3 上図に示されている. 土地統合不可能 
の場合の最適配置は，前述の通り，土地代によらず(M0)となるので 移動費用は一定である．施設数も決まっているから，土地費用は土 地代に比例して増大し, 総費用も直線的に増大する。これに対して, 土地統合可能の場合は配置を変えて施設複合化が進むため, 移動費 用は増加するが逆に土地費用の増加は抑えられ，総費用の増加も緩 やかに転じていく．土地代が上昇していくほど両者の総費用の差は 大きくなり，複合化を進める意義が大きくなっていくことがわかる。

（3）施設数内生の場合の複合化

施設数を内生化したモデルの最適配置は, 土地統合可能な場合, 図 $2(\mathrm{~F} 0) \sim(\mathrm{F} 3)$ のようになる.土地代がかからない(F0)の最適配置で は総施設数は 15 であるが，偶然場所の一致する施設もあるため，施 設設置場所数は 9 ケ所である. 施設数所与の場合と比べて移動費用 の重みが相対的に小さい図書館は，施設数を減らしても総費用の増 加は少ないため, 最小限の1施設しか設置されず，代わりに移動費 用の重みが大きく，施設数を増やすことによって総費用を抑えるこ とができる他の施設は多く設置されていることに注意されたい，土 地代の上昇に伴ってまず(F1)で幼稚園が 1 施設减少するが, その後, 各種の施設数は変わらない. 代わりに, $(\mathrm{F} 2)(\mathrm{F} 3)$ と移動費用换算係数 が比較的小さい児童館や図書館が他の施設に統合していくことによ り，施設設置場所数を $7,6,5$ 施設一と減少させている.この複合化 過程も，移動費用より複合化による土地費用の節約が優先されるこ とによるものである.また, 施設数所与の場合よりも低い土地代で, 施設数の中で最大の 5 施設に至っている。このように，土地代が高 くなると複合化が有利になり同じ場所に複数の施設が立地するパタ ーンが最良になることは，施設数所与の場合と同様である.

一方，土地統合不可能な場合，土地代がかからないときは(F0)が 最適配置となるが，土地代の上昇に従ってその後は(FN1)〜(FN6) と変化していく．複合化で施設設置場所数を减少させても土地費用 の减少につながらないため，施設数を减らすことによって総費用を 堿少させていく変化が見られる. 総施設数は 15 から9まで順次减少 していく一方，施設設置場所数はそれほど减少せず，ケース16のよ うに逆に増える場合も見られる。このように，土地統合が不可能な 場合は土地代の增大は施設数の減少をもたらすことがわかる。

施設数内生の場合について，土地代の変化による総費用およびそ のうちの移動費用分の変化は図 3 下図に示されている．総費用は施 設数所与の場合よりも建設費用の分だけ高くなっていることに注意 されたい. 土地統合不可能の場合，土地代が上昇すると施設数が減 るため移動費用も上昇する．また施設設置場所数の方は減らないの で土地費用もそれほど堿らない。これに対して，土地統合可能の場 合は，施設複合化が進んでも施設数は堿らないため，移動費用はほ とんど増加しない．また，設置場所数は減少するため土地費用も漸 増するのみである。したがって，土地代が増えていくほど土地統合 可能の場合の方が総費用は低くなっていき，複合化を進める意義が 大きくなっていくことがわかる.

\section{5. 結論と今後の課題}

本稿では，土地の有効利用という側面に着目し，空間複合型施設 の最適配置を離散立地モデルとして定式化し，地価上昇に伴い施設 の複合化が進行する仕組みを再現した. 主な結論は次の通りである. (1) p-メディアン問題をベースにした施設数所与の場合扩よび施設数
内生の場合の空間複合型施設配置問題を線形 0-1 計画問題として 定式化した。比較対照のためにそれぞれ土地統合可能な場合に対 して土地統合不可能な場合も定式化した。

(2) 東京都心区から抽出したネットワークを対象に, 幼稚園・小学 校・児童館・図書館の 4 種の施設を設置する問題の解を求めた. 施設数所与のモデルでは, 土地代が上昇するのに伴って, 移動費 用よりも複合化による土地費用の節約が優先され，施設同士が空 間的に複合化していく過程が再現された. 移動費用は増加してい くが逆に土地費用の増加は大きく抑えられ，土地統合不可能な場 合と比へて総費用の増加は小さくなっていく, すなわち複合化を 進める意義が大きくなっていくことが明らかとなった。

(3) 施設数内生モデルでは, 土地代の上昇に伴って，施設数はあまり 減少させず，複合化を進行させて施設設置場所数を堿らしていく ことが分かった。一方, 土地統合不可能の場合は土地代の増大は 直接的に施設数の堿少をもたらす. 総費用については, 土地統合 不可能の場合は移動費用も土地費用も增加していくのに対し，土 地統合可能の場合は移動費用も土地費用も漸増寸るのみで, やは り複合化を進める意義が大きくなっていくことが分かった。

本論文の結果は，対象ネットワークの粗密（ノード数の大小）に 依存する，もしもっと密であれば，本稿では複合施設化しているケ ースでも少し離れて立地した方がよい場合も考えられる，離散立地 問題として数理計画によるアプローチを採用したが、これは複合す る/しないという変数が離散型の問題に合致していたためである. しかし，規範解を導出するためには解析的アプローチを試みること も重要であろう。また，本論文における立地評価は平均移動距離 (Average Distance)に基づいたものであるが，被覆(Coverage)や最大距 離(Maximum Distance)を評価指標とする場合も同様なモデル化が可 能である．また，本モデルの現害への適用に当たっては，土地費用 に対する移動費用の重みの設定方法や土地費用の節約分等が丁寧に 検討されなければならない.これらについては今後の課題としたい.

有益なご示唆を戴いた筑波大学腰塚武志教授，中央大学田口東教 授, 南山大学鈴木敦夫教授, 慶應義塾大学栗田治助教授に感謝致し ます，なお，本研究は日本学術振興会科学研究費補助金に上る成果 の一部である.

\section{参考文献}

1) Daskin, M.S.: Network and Discrete Iocation: Models, Algorithms, and Applications. Wiley. 1995

2) 岸本達也 :「多層構造モデルによる複合施設の最適配置」, 日本建築学会計 画系論文集, 529, 233-239, 2000 年 3 月.

3) Mirchandani, P.B. and R.L. Francis: Discrete Location Theory. Wiley. 1990

4) 日本建築学会: 地域施設の計画, 丸善, 1995 .

5) 斎尾直子・藍澤宏・土本传一・村山直樹：「公立小・中学校の地域施設とし ての機能複合化に関する研究」，日本建築学会計画系論文集，523，131-138, 1999 年 9 月.

6) 鉿木 勉：门土地費用に着目した施設複合化と配置のモテル分析」, OR 学会 2000 年度秋季研究発表会アブストラクト集, 66-67, 2000.

7) 鈴木 勉:「サービスの組合せに着目した複合サービス施設の最適配置」, 日 本建築学会計画系論文集, 540, 189-195, 2001 年 2 月.

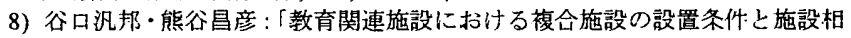
互関連の特性について一都市における教育関連施設の複合化計画に関す る研究(1)-」，日本建築学会計画系論文報告集，336，121-131，1984 年 2 月．

9) 上野淳・本野純: 「公立小・中学校と地域公共施設の複合化事例における建 築計画と管理・運営の実態」, 日本建築学会計画系論文集, 493, 117-124, 1997 年 3 月

10)屋敷和佳・谷口汎邦・山口勝巳 : 「建物区分所有による複合形態と複合の経 緯一学校と地域施設の複合化に関寸る研究 その 1 -1, 日本建築学会計 画亲論文報告集, $452,65-74,1993$ 年 10 月。

（2000年11月16日原稿受理，2001年 4 月 5 日採用決定） 